\title{
ERRATUM
}

Antonio Nogueira De Almeida - Raul Marino Jr •

Paulo Henrique Aguiar - Manoel Jacobsen Teixeira

\section{Hemispherectomy: a schematic review of the current techniques}

Published online: 24 May 2006

C) Springer-Verlag 2006

\section{Neurosurg Rev (2006) 29:97-102}

Unfortunately, the names of two authors have been given incorrectly in the affiliations.

The correct affiliations are given here in full.

The online version of the original article can be found at: http://dx. doi.org/10.1007/s10143-005-0011-7

A. N. De Almeida - R. Marino Jr .

P. H. Aguiar - M. J. Teixeira

Departamento de Neurologia do Hospital das Clinicas da

Faculdade de Medicina da Universidade de São Paulo,

São Paulo, Brazil

A. N. De Almeida $(\square)$

Instituto Neurológico de São Paulo,

Rua Maestro Cardim,

808, Liberdade,

CEP 01323-001 São Paulo, SP, Brazil

e-mail: almeidaan@globo.com

Tel.: +55-11-96592857

Fax: $+55-11-31419556$ 